Roger Y Chao Jr. (City University of Hong Kong)

\title{
East Asian Regionalism: Perspectives, Realities and the Future
}

\section{Introduction}

From the mid-1900s onwards, East Asian political developments, the East Asian Miracle, and regional integration initiatives in the region have facilitated a growing scholarship in East Asian political economy and regional issues. The 1997 Asian Financial Crisis and the recent global financial crises (2007 sub-prime crisis and the on-going European sovereign debt crisis) further highlighted the region. The former focused on the region's weaknesses, while the later focused on its strengths in search of an Asian-led solution (in terms of economic capacity and growth) to support global economic growth and eventually contribute to the end of the recent string of global financial crises.

East Asian regionalism came forth through a series of failed and successful regional integration initiatives. These initiative included the Asian Relations Conferences (1940s-50s), initiatives leading to the establishment of the Association of South East Asian Nations (ASEAN) in 1967, and the current East Asian frameworks: ASEAN plus three (APT), East Asian Summit (EAS), and the expanded EAS with the entry of the USA and Russia in 2011. These regional integration initiatives have initially focused on security and/or economic issues bounded by geography and nation states, shed its geographic and national boundaries, and incorporated a coalition of social forces (e.g. markets, private trade, investment flows, international organizations and civil society just to name a few) into the regional integration processes.

East Asian regionalism seems to have evolved from old regionalisms to new regionalisms. The former focused on security and/or economic bounded by geography and focused on nation states as actors, while the latter incorporates various actors, be it agency or structures, without boundaries (Ravenhill 2001, 2009, Robertson 2008). In spite of all the challenges to East Asian regionalism, East Asian political frameworks are in place, East Asian regional production networks are considered the most integrated in the world, and regional financial initiatives have 
taken off. Is this East Asian regionalism, and are we nearing the formation of an East Asian Community?

From a financial integration, financial regulation, and education perspective, however, East Asian regionalism has either stagnated or even regressed. Furthermore, US re-engagement in the region and the increased tension over the South China seas ${ }^{1}$ tend to challenge further developments in East Asian regionalization outside of the economic space.

This paper is a mini-scoping study to present the realities that East Asian regionalism is still lap-sided: economic regionalism is highly developed, while other key components (regional financial and financial regulation integration, education collaboration, and a regional political framework) are developing at a slower rate, stagnating, and regressing. The three sections of this paper: development of East Asian regionalism; challenges to East Asian regionalism; and the future of East Asian regionalism (conclusions and recommendations) aim to present the reality of East Asian regionalisms, provoke awareness of false perspectives, and present a recommendation towards a balanced and more sustainable East Asian regionalism and the formation of a real East Asian Community.

\section{Development of East Asian regionalism}

\subsection{Historical development of East Asian regionalism}

The historical evolution and development of Asian regionalism was studied by $\mathrm{He}$ (2004), He \& Inoguchi (2011) and Acharya (2012) from ideological and capacitylegitimacy perspective respectively. Both scholars explored the nature, meaning and power politics of Asian regionalism leading to an ASEAN-led regionalism and implicitly points to a path dependency in East Asian regionalism.

Following the end of the $2^{\text {nd }}$ world war and the decolonization of Asia, India and eventually China advanced Asian regionalism through the Asian Relations Conferences during the 1940-50s; the US, their western (Australia, France, Great Britain, and New Zealand) and Asian (Thailand, Pakistan, and the Philippines) allies established the now defunct South East Asian Treaty Organization (SEATO) in 1954 to prevent the spread of communism in the region. However, India and China's lack of capacity and the US's lack of legitimacy resulted to the failure of the above mentioned regional initiatives (Acharya, 2012). The failure of early Asian regionalization initiatives, however, provided the groundwork for South

\footnotetext{
In April 2012, China and the Philippines escalated the territorial dispute situation over the South China Seas. Each country is claiming ownership of an island in the South China Seas and resulted to a naval standoff in the area. This, however, is only part of the tensions involving other countries (e.g. Brunei, Japan, Malaysia, Taiwan, Vietnam) claiming in part or as whole territories in the area.
} 
East Asian regionalization initiatives in spite of Japan's legitimacy related failed bid to lead Asian regionalism.

The Federation of Malaya's (composed of Sabah, Sarawak, Singapore and Malaya) independence and the establishment of Malaysia in 1957 and 1963 respectively facilitated the establishment of the Association of Southeast Asia (ASA) by Thailand, Malaysia and the Philippines in 1961 and the proposed Confederation of Malaysia, Philippines, and Indonesia (MAPHILINDO) in 1963. The IndonesiaMalaysia conflict and Singapore splitting out from Malaysia in 1965, however, hindered the success of the former initiatives and directed the establishment of the Association of South East Asian Nations (ASEAN) in 1967 by its five founding member nations: Indonesia, Malaysia, Philippines, Singapore, and Thailand. Malaysia. ASEAN's resilience have been tested by internal (e.g. Malaysia-Philippine Sabah conflict; Singapore-Indonesia conflict; and the Vietnamese occupation of Cambodia) and external challenges with alternative (and mostly failed) non ASEAN-led regionalization frameworks. In fact, ASEAN's membership expanded to 10 member countries counting Brunei Darussalam (1984), Vietnam (1995), Laos (1997), Myanmar (1997) and Cambodia (1999).

ASEAN-led regionalization initiatives use the ASEAN way, the use of dialogue and consensus building, to focus on regional economic and security issues without the hegemonic appeal of the major powers. ASEAN established the ASEAN Free Trade Area (AFTA) and the ASEAN Regional Forum (ARF) in 1992 and 1994 respectively representing regional economic and political/security initiatives within the region. Further in 1997, the ASEAN Vision 2020 was established to form the ASEAN Community by 2020 (later moved earlier to 2015) based on three pillars: ASEAN Economic Community (AEC); ASEAN Security Community (ASC); and the ASEAN Socio-Cultural Community (ASCC). ASEAN's regionalization project was later expanded to include China, Japan and South Korea under the ASEAN plus three (APT) framework in 1997; and the East Asian Summit (EAS), which adds Australia, New Zealand and India in 2005, and the US and Russia in November 2011.

In spite of the 1997/98 Asian Financial Crisis (AFC), the APT framework prospered, strengthened and deepened especially in terms of economic integration. The AFC, in fact, heightened the reality of East Asian economic interdependence and the need to maintain regional peace, stability and security, which enhanced and hastened the East Asian regionalization processes.

\subsection{Regional economic integration}

During the post-war reconstruction period and the decolonization of South East Asia, the establishment of the Bretton Woods institutions (e.g. International Monetary Fund and World Bank), the Asian Development Bank, and the World 
Trade Organization in 1995, 1966 and 1995 respectively constructed a global and regional economic discourse with a neo-liberal agenda. Policy prescriptions such as decentralization, deregulation, privatization, liberalization, fiscal discipline and privatization have been promoted along with open trade regime facilitating the establishment of a global marketplace for goods and services. Within this context and in spite of the idea of an East Asian Community advanced by the East Asian Vision Group in 2001, it is no surprise that East Asian regional initiatives have focused on regional economic issues and the formation of an East Asian Economic Community in spite of the notion of an East Asian Community.

East Asian regional economic integration can be seen in the growing number of bi-lateral and multi-lateral free trade agreements (FTA) between APT/EAS member nations, increased intra-regional trade, and the formation of East Asian regional production networks. Furthermore as a response to the 1997/98 Asian Financial Crisis, various regional financial initiatives including the Chang Mai Initiative (CMI), Chang Mai Initiative Multi-lateralization (CMIM), Asian Bond Market Initiative (ABMI), and the Asian Bond Funds (ABF) moving towards the development of an East Asian financial market.

Since the establishment of the ASEAN Free Trade Area (AFTA) in 1992 and enhanced by the failure of World Trade Organization's Doha round, East Asia have been constructing its own economic sphere with the proliferation of various bi-lateral and plural-lateral FTAs within East Asia. Starting with the JapanSingapore Economic Partnership Agreement (JSEPA) in 2002, bi-lateral FTAs among APT/EAS economies have been increasing. Several ASEAN plus 1 FTAs (e.g. ASEAN-China (2002); ASEAN-Japan (2003); ASEAN-South Korea (2006); ASEAN-India (2009); ASEAN-Australia New Zealand (2009)) were signed and currently in effect. Furthermore, the institutionalization of broader free trade areas (e.g. East Asia Free Trade Area (AEFTA) and the Comprehensive Economic Partnership for East Asia (CEPEA) under the APT and EAS frameworks respectively) have been proposed, studied and currently negotiated to establish an East Asian Economic Community (EAEC), which hosts a population of 3.3 billion, 17.0 billion USD in GDP, and 9.98 billion USD trade volume based on 2010 figures (compiled from WTO 2011 report).

In 2010, intra-APT trade accounts for $51.5 \%$ of total ASEAN trade, with intra-ASEAN, China, Japan, and South Korea contributing to $24.5 \%, 11.6 \%$, $10.5 \%$, and $4.9 \%$ of total ASEAN trading volume (Compiled from ASEAN statistics 2011). Furthermore as shown in table 1, China, Japan and South Korea exports $12.1 \%, 27.5 \%$, and $29.8 \%$ and imports $30.1 \%, 22.1 \% \%$, and $32.1 \%$ to/from each other. If we consider Hong Kong, Macau, and Taiwan (shown as NEA plus) $\%$ exports increases to $25.9 \%, 34.3 \%$, and $35.2 \%$ respectively for China, Japan, and South Korea, while China's \% import also increases to $38.4 \%$. 
Table 1. North East Asian Trade (\% of national trade volume (2010).

\begin{tabular}{|c|c|c|c|c|}
\hline & Export (\%) NEA & $\begin{array}{c}\text { Export (\%) NEA } \\
\text { plus }\end{array}$ & Import (\%) NEA & $\begin{array}{c}\text { Import (\%) NEA } \\
\text { plus }\end{array}$ \\
\hline China & 12.1 & 25.9 & 30.1 & 38.4 \\
\hline Japan & 27.5 & 34.3 & 22.1 & 22.1 \\
\hline South Korea & 29.8 & 35.2 & 32.1 & 32.1 \\
\hline
\end{tabular}

Source: WTO 2011 (based on each country's 5 largest trading partners)

Note: NEA (China, Japan, \& South Korea); NEA plus (NEA plus Hong Kong, Macau, \&Taiwan)

Furthermore, the establishment of the above mentioned AFTA along with the numerous bilateral and multi-lateral free trade agreements has facilitated the development and establishment of regional production networks in East Asia. The shift in production patterns, increased trade and consumption facilitated in part by globalization, but mostly heightened by various regional integration initiatives contributed to the formation of East Asian regional production networks. Globalization, its market integration process and the shift in production processes have resulted to production shifts from the developed to the developing nations, cheaper products, a redistribution of income and employment across and within nations (Spence 2011).

Aside from the traditional nation state-bounded production units, multinational and transnational corporations have increasingly expanded its operations offshore and even operate in multiple nation states. In most cases, foreign direct investments, mergers and acquisitions and joint ventures are used by these corporations to exploit competitive advantages in search of higher productivity, reduced production cost, geographical marker significance and/or opportunity to enter into new markets.

The East Asian regionalization project, however, facilitated regional production patterns to shift and establish the East Asian regional production networks. Various regional multinational and transnational corporations fragmented their production process into production blocks. These production blocks are subsequently located in other nations based on its economic viability, largely determined by a large cost savings and service link costs to connect the different production blocks (ADB 2008, WTO 2008, Kimura \& Obashi 2011). Normally, these production networks exist in locations characterized by low trade barriers, good locational advantages including ease of coordinating various production blocks, availability of related support industries, and even access to local markets, which are often the environment within regional free trade zones. As such, developing nation states, mostly from South East Asia and China, facilitate the provision of policy incentives (e.g. flexible labor laws, the establishment of industrial/export processing zones, and tax holidays or exemptions) to improve their own comparative advantage in attracting some of these production blocks. 
East Asian regional production networks, the intra-regional competition for production blocks among the region's developing nations should be seen as a result of structural changes in the global and regional production systems. The global and regional search for comparative advantages resulted to geographical concentrations and specialization of production within the broader global supply chain (WTO 2008, Kimura \& Obashi 2011).

\subsection{Regional financial integration}

Aside from its effect on East Asian political framework (APT), the 1997/98 Asian financial crisis also facilitated the start of East Asian financial integration. East Asian nations were shocked and realized its susceptibility to global capital flows and financial shocks, their interdependency among East Asian nations and the urgent need for regional cooperation and integration to create stability and prosperity in the region, which includes the establishment of a regional financial market. In fact, the Chiang Mai Initiative (CMI), Asian Bond Market Initiative (ABMI), Asian Bond Funds (ABF) and Chiang Mai Initiative Multilateralization (CMIM) were established in 2000, 2003, 2003 and 2009 respectively (Henning 2002, 2009, Hyun \& Jang 2008). Furthermore in 2011, the establishment of the ASEAN plus three Macroeconomic Research Office (AMRO) complements the above mentioned initiatives. As the CMIM's surveillance unit, AMRO contributes to regional risk management and swift implementation of remedial actions within the APT countries.

The CMI formed a series of bilateral currency swap agreements, which was eventually evolved into the CMIM, a multilateral currency swap arrangement among APT member nations with an initial reserve pool of USD 120 billion (expanded to USD 240 billion in 2012) in 2010. AMRO's establishment and key role in regional economic surveillance is meant to support the CMIM and the region's need for self-sufficiency in economic monitoring and financing short term capital liquidity requirements. Furthermore, the finance ministers of the APT nations established the ABMI to develop an efficient and liquid (local currency) bond market in Asia targeting Asian savings for Asian investments. ABMI is also aimed at correcting and reducing the region's financial maturity and currency mismatches which was seen as a cause of the 1997/98 Asian financial crisis. As of 2011, the total local currency bonds outstanding in East Asia is USD 5.7 trillion, which have been growing at $15.1 \%$ annual average over the past 5 years.

The ABF, on the other hand, was established by the Executives' Meeting of East Asia and Pacific Central Banks (EMEAP), comprised of the Central Banks of the eleven East Asian Nations ${ }^{2}$ and managed by the Bank for international Settle-

2 ASEAN 5 (Indonesia, Malaysia, Philippines, Singapore and Thailand), Hong Kong, China, Japan, South Korea, Australia and New Zealand 
ments (BIS) in Basel, Switzerland. In spite of being launched only in 2004, ABF 2 two phases has only been successfully implemented in 2011.

Given the developments of East Asian regionalism presented above, perceptions of East Asian regional integration are easily formed. In spite of its advance in economic and financial integration, East Asia still has a long way to go as discussed in the next section. Furthermore, East Asian regionalism should not be seen in terms of economic integration or its ongoing financial integration, but as a broader regional integration project (such as the establishment of an East Asian Community), which includes socio-economic and political dimensions.

\section{Challenges to East Asian Regionalism}

The journey to East Asian regional integration is still a long way off: be it in terms of economics, socio-cultural or political. He (2004) \& HE \& Inoguchi (2011) present a number of key challenges to East Asian regionalisms. Multiple Asian regionalism frameworks, cultural diversity, internal (or the potential) conflict within the region and an economy that is more globally then regionally integrated are posed as key challenges to East Asian regionalism. Furthermore, the strong economic focus on economic regionalism has resulted to a lap-sided development of East Asian regionalism at the expense of socio-cultural (shown in terms of higher education in this paper) and political regional developments.

Economic regionalism leading to the formation of an East Asian economic community is in its advance stages with the various free trade agreements, the regional production networks, and financial integration initiatives leading to the development of a regional financial market. The complexity of the numerous free trade agreements, the initial stages of its financial integration, and the lack of a regional financial regulatory architecture challenges further integration as discussed in this section. Furthermore, the lack of a strong regional cooperation in education and the multiplicity of political frameworks challenge East Asian regionalisms. This section presents the realities of East Asian regionalisms and the challenges the region has to face primarily in terms of economic, socio-cultural and political regionalisms.

\subsection{Economic regional integration}

Challenges to East Asian economic regionalism should be seen with the numerous free trade agreements among East Asian nations, the early stages of financial integration, the lack of a formal regional institution and the multiplicity of political frameworks in East Asia.

In spite of the advances of East Asian economic regionalism, the multiplicity of bilateral and multilateral free trade agreements challenges further economic integration. In fact, a number of East Asian scholars (Jetro 2003, Park, Urata 
\& Cheong 2005, Kawai \& Wignaraja 2008, 2010, Zhang \& Shen 2011) have suggested sorting out these agreements and merging them into an East Asian Free Trade Agreement in spite of the challenges involved in the process. AFTA's success with eradicating/reducing tariff barriers within the ASEAN region has been commendable. Replicating ASEAN's success with AFTA in East Asia, however, is challenging given the geo-political situation in East Asia, China, Japan and South Korea's economic competition with its other, and ASEAN's ongoing challenge of reducing non-tariff barriers. Ravenhill (2009) explained that the proliferation of free trade agreements in East Asia does not translate to increased economic integration, but a result of the economic integration used by nation states to increase their political influence.

In terms of East Asian financial integration, there are a number of issues that must be addressed. Firstly, there are two organizations, ASEAN plus three and EMEAAP, facilitating the development of regional financial markets. Although the former focused on developing local currency denominated bond market and the latter in USD denominated bonds and its corresponding investments, there is a need to properly define regional boundaries, institutional responsibility and institutionalize regional financial markets and its regulation. The need for a stronger cooperative mechanism for crisis prevention, management and resolution was stressed by Kuroda \& Kawai (2003) and having a definite framework covering regional financial integration is a necessity to regional financial integration. In fact, Kim \& Lee (2012) quantitative study on East Asian real and financial integration concluded that real (economic) integration have progressed after the 1997/98 financial crisis but proceeding faster than financial integration in the region. Further, it also showed that East Asian global financial integration is progressing faster than its regional financial integration.

Studying East Asian financial integration, Buckley (2011) noted that the IMF's poor record in handling economic crises, its Washington Consensus based policy prescriptions and its poor handling of the 1997/98 Asian financial crisis resulted to East Asia's drive for self-sufficiency in financing, macroeconomic monitoring and the formation of a regional financial markets for local and foreign currency denominated assets. In the same paper, Buckley argued that current regional financial integration initiatives should be the basis for the formation of an Asian Monetary Fund, which will promote economic policies in the region, give a larger role to national governments, equity investment and domestic demand in contrast to the Washington Consensus' foreign debt financing and export revenue focus.

In terms of East Asia's regional financial regulation, Volz (2012), studying the European monetary and financial integration experience, advanced some lessons for East Asian financial integration. These include the need for a crisis prevention and resolution mechanism, strengthening of surveillance and monitoring of regional financial markets, and the need for swift bank recapitalization after a crisis. Similarly, Chao (forthcoming) have argued of the need for an East Asian 
financial regulatory framework/architecture, which facilitates the region to voice its concerns and needs into the global financial regulatory architecture, create a firewall against global or other region's financial crises, and facilitate the development and further integration of the region's financial markets.

\subsection{Regionalization of higher education}

East Asian Regionalisms have mostly been focused on economics although there have been some initiatives in East Asian higher education regionalization and the establishment of East Asian political frameworks. Regionalization of higher education facilitates socio-cultural integration through the formation of a regional identity, a greater understanding of the multiple cultures within the region, aside from the formation of various regional public goods. It also facilitates intra-regional migration and the establishment of a regional workforce to support the economy, real or knowledge-based.

Furthermore as mentioned earlier in this paper, there is a need to define regional boundaries and the institutions responsible for regionalisms. In East Asia, there are a number of broad regional frameworks: ASEAN plus three, East Asian Summit, and the recent East Asian Summit plus US and Russia. This is further complicated sub-regional (e.g. Greater Mekong Sub-region, Indonesia-MalaysiaThailand Growth Triangle, Brunei-Indonesia-Malaysia-Philippine Growth Area) and the broader regional frameworks (e.g. Asia Pacific Economic Cooperation (APEC)).

Regionalization of East Asian higher education has lagged behind Europe and even South East Asia. In Europe, the 1999 Bologna Process have pushed the regionalization of higher education agenda, established a multiple stakeholder approach to harmonize European higher education and establish the European Higher Education Area late 2010. Furthermore, the Bologna Process' influence have gone beyond its boundaries and influenced other regions (e.g. South East Asia and Asia Pacific) to replicate or base their own higher education initiatives on it (Chao, 2011).

In South East Asia, regionalization of higher education initiatives includes the establishment of the ASEAN University Network (AUN), AUN for Quality Assurance (AUN-QA) and the ASEAN Quality Assurance Network (AQAN) in 1992, 1998 and 2008 respectively. In 2004, 2009 and 2010 respectively, the ASEAN Quality Assurance Framework, the ASEAN Credit Transfer System (ACTS) and the Malaysia Indonesia Thailand (MIT) student mobility program were established following the developments of European higher education within its own regional context (Chao, 2011). Furthermore, the United Nations Educational, Scientific and Cultural Organization (UNESCO) 1983 Regional Convention of Studies, Diplomas and Degrees in Higher Education in Asia and the Pacific was only fully ratified by its 21 participating nations, resulting to the recently 
revised convention in 2011. Lastly since 2007, the South East Asian Ministers of Education Organization - Regional Center for Higher Education and Development (SEAMEO-RIHED) have been promoting the idea of a South East Asian higher education area.

In East Asia, however, initiatives toward regionalization of higher education can only be seen as a future expansion of the South East Asian Higher Education Area into an East Asian Higher Education Area or as part of a broader initiative such as the Brisbane Communiqué 3 . In 2010, China, Japan and South Korea launched the Collective Action for the Mobility Program of University Students (Campus Asia), which can be seen as a regionalization of higher education project among the three largest economies and mobile student exporters in the region.

\subsection{East Asia's multiple frameworks}

Another challenge to East Asian regionalisms is the multiple political frameworks with which East Asia works. Multiple perspectives and initiatives towards East Asian regionalisms complicate the integration processes, be it in economics, finance, education and/or politics. The definition of East Asia is in itself vague. Does it comprise the geographical boundaries of the ASEAN plus three nations as used in this paper, Is it the East Asian Summit (APT plus Australia, New Zealand and India) or is it the expanded East Asian Summit which already includes the US and Russia?

Furthermore, the question of regional leadership has been advanced by Acharya (2012) using a capacity-legitimacy framework ${ }^{4}$ and suggests the difficulty of sustaining an ASEAN-led regionalism, which is institutionally weak and has a poor policy implementation record. The Japan-China economic and political competition within the region, the US and Russia's entry to the East Asian Summit late 2011, and the question of a continued weak ASEAN-led regionalism brings out questions of East Asian regional leadership, structures and power dynamics as well as the direction of East Asian regionalisms in the future. This is further complicated by the broader regional projects such as the Asia Pacific Economic cooperation (APEC), the Trans-Pacific Economic Partnership, and the various inter-regional initiatives (e.g. Asia Europe Meeting (ASEM), South Asian Association for Regional Cooperation (SAARC), Pacific Islands Forum (PIF) and even Central Asia Regional Economic Cooperation (CAREC)).

3 Adapted in Brisbane, Australia on April 2006, the Brisbane Communiqué is a ministerial-level agreement from 27 countries (later expanded to 52 countries) across the Asia Pacific region to collaborate on a number of broad higher education initiatives to encourage and facilitate regional student and academic mobility and exchange.

4 Acharya (2012) advanced that the lack of capacity or legitimacy of a nation state resulted to their failed regional leadership role attempt. Japan, China, India and even the US failed attempts to gain regional leadership role in East Asia and the emergence of an ASEAN-led regionalism is explained using this framework. 
This same argument can be seen in the developments of East Asian economic and higher education regionalisms. ASEAN regional integration is progressing a lot faster than East Asian regional initiatives. In economics, ASEAN economic integration is in its advanced stages, while East Asian economic integration is still weak. In fact, the ASEAN Economic Community is set to be in place by 2015, while an East Asian Free Trade Agreement initiative is nowhere in sight. Latest developments are seen in the planed negotiation of a China, Japan and South Korea Free Trade Area later this year shows the multiplicity of East Asian economic frameworks. In higher education, East Asian regionalization of higher education is proceeding from multiple frameworks too. An expansion of the South East Asian higher education area, the China, Japan and South Korean Campus Asia initiative and the Brisbane Communiqué covering the Asia Pacific.

\section{Conclusion}

The perception of East Asian regionalism is heavily skewed to its economic aspect. The successful ASEAN Free Trade Area (AFTA), the various ASEAN based free trade agreements with China, Japan and South Korea, and the establishment of the various East Asian regional production networks points to East Asian economic integration. Furthermore, the historical development of the ASEAN, ASEAN plus three framework and the East Asian regional financial markets especially after the 1997/98 Asian financial crisis further enhances this perception.

The reality of East Asian regionalism, however, is still heavily challenged at economic, socio-cultural and political dimensions. East Asian economic regionalism is actually based on a central ASEAN base being networked to the North East Asian nations (China, Japan, and South Korea). The various free trade agreements have failed to facilitate an East Asian Free Trade Area, while the North East Asian nations are in the process of negotiation their own free trade area. Furthermore, East Asia is mostly an export based region manufacturing for the rest of the world making the region's economic integration more part of the globalization project than a regional initiative.

East Asian regional financial markets are still more integrated to global financial markets than in the region, while it lags behind real economic integration in the region. There is a lack of a regional financial regulatory architecture to facilitate further regional financial integration and create a firewall against global or other region's financial crises. Furthermore, East Asian regionalization of higher education is almost inexistent and most of its related initiatives are done either at the ASEAN, Asia Pacific or the North East Asian level. Lastly, the lack of a definite single East Asian framework challenges the definition of East Asia and its boundaries, East Asian regional integration covering economics, finance, higher education and even its political nature. This is visible in the various East 
Asian frameworks for political and economic dialogues, the various institutions (ASEAN plus three and EMEAP) that promotes the establishment of East Asian regional financial markets, and the multiple regionalization of higher education initiatives which might lead to the creation of a future East Asian higher education area.

As such, East Asian regionalism is defined ambiguously, facilitated by multiple institutions, and substantially lap-sided skewing towards economic regionalism. East Asian Regionalism should be seen in terms of the formation of an East Asian community based on three pillars: economic; socio-cultural and political, as proposed by the East Asian Vision Group in 2001. East Asia and its boundaries should be explicitly and unanimously defined and regionalization initiatives coordinated by the multiple institutions involved. The multiple free trade agreements should be collated, harmonized and fused to establish an East Asian Free Trade Area. Similarly, regional financial and higher education initiatives should be rationalized towards the formations of regional financial and higher education markets under one definite and agreed East Asian framework. Lastly, regional institution building is necessary to facilitate a greater regional focus and actually realign the multiple regionalization initiatives, be it for economics, finance, higher education or politics, towards the formation of a regional identity and an East Asian Community.

\section{References}

Acharya, Amitav. (2012). Foundations of Collective Action in Asia: Theory and Practice of Regional Cooperation. ADBI Working Paper Series 334. Tokyo: Asian Development Bank Institute.

Asian Development Bank. (2008). Emerging Asian Regionalism: a Partnership for Shared Prosperity. Manila: Asian Development Bank.

Buckley, Ross. (2011). East Asian Financial Integration: A Road Ahead. University of New South Wales Faculty of Law Research Series 2011. Working Paper No. 57. URL: <http: law.bepress. com/unswwps/flrps11/art57/> [accessed September 9, 2012].

Chao, Roger Jr. (2011). "Reflections on the Bologna Process: the making of an Asia Pacific Higher Education Area”. European Journal of Higher Educaiton, 1(2-3): 102-118.

He, Baogang. (2004). "East Asian Ideas of Regionalism: a Normative Critique”. Australian Journal of International Affairs, 58(1): 105-125.

He, Baogang and Takashi Inoguchi. (2011). "Introduction to ideas of Asian Regionalism". Japanese Journal of Political Science, 12(2): 165-177.

Henning, C. Randall. (2002). "The Chiang Mai Initiative". In East Asian Financial Cooperation: Policy Analysis in International Economics 68. Washington D.C.: Peterson Institute of International Economics.

Henning, C. Randall. (2009). "Policy Brief". Peterson Institute for International Economics. Accessed December 4, 2011. URL: http://www.iie.com/publications/pb/pb09-5.pdf [accessed September 9, 2012]

Hyun, Suk and Hong Bum Jang. (2008). "Bond Market Development in Asia". United Nations Economic and Social Commission for Asia and the Pacific. URL: <http:// www.unescap.org/pdd/ projects/bondmkt/1_bond_development.pdf $>$ [accessed September 9, 2012]. 
Japan External Trade Organization (JETRO). (2003). Prospects for Free Trade Agreements in East Asia. Tokyo: Japan External Trade Organization .

Kawai, Masahiro and Ganeshan Wignaraja. (2008). Regionalism as an Engine of Multilateralism: A Case for a Single East Asian FTA. ADB Working Paper Series on Regional Economic Integration 14. Manila: Asian Development Bank.

Kawai, Masahiro and Ganeshan Wignaraja. (2010). Asian FTAs: Trends, Prospects \& Challenges. ADB Economics Working Paper Series 226. Manila: Asian Development Bank.

Kim, Soyoun and Jong-Wha Lee. (2012). "Real and Financial Integration in East Asia". Review of International Economics: 332-349.

Kimura, Fukunari and Ayako Obashi. (2011). Production Networks in East Asia: What We Know So Far. ADBI Working Paper Series 320. Tokyo: Asian Development Bank Institute.

Kuroda, Haruhiko and Masahiro Kawai. (2003). Strengthening Regional Financial Cooperation in East Asia. Tokyo: Policy Research Institute, Ministry of Finance, Japan.

Pak, Yong-Chol, Shujiro Urata and Inkyo Cheong. (2005). The Political Economy of the Proliferation of FTAs. Seoul: Korea Economic Research Institute.

Ravenhill, John. (2001). APEC and the Construction of Pacific Rim Regionalism. Cambridge: Cambridge University Press.

Ravenhill, John. (2009). The "New East Asian Regionalism": A "Political Domino" Effect?. United Nations University - CRIS Working Paper Series W-2009/11. Brugge: United Nations University - Comparative Regional Integration Studies.

Robertson, Susan. (2008). 'Europe/Asia' Regionalism, Higher Education \& the Production of World Order". Policy Futures in Education, 6(6): 719-729.

Spence, Michael. (2011). "The Impact of Globalization on Income and Employment: the Downside of Integrating Markets". Foreign Affairs, 90(4): 28-41.

Volz, Ulrich. (2012). Lessons of the European Crisis for Regional Monetary and Financial Integration in East Asia. ADBI Working Paper 347. Tokyo: Asian Development Bank Institute.

World Trade Organization (WTO). (2008). World Trade Report 2008: Trade in a Globalizing World. Geneva: World Trade Organization.

Zhang, Yunling and Minghui Shen. (2011). The Status of East Asian Free Trade Agreements. ADBI Working Paper 282. Tokyo: Asian Development Bank Institute. 